\title{
ANALYSIS OF THE FACTORS AFFECTING PUBLIC BEEF CONSUMPTION IN PANDAN SUB-DISTRICT, CENTRAL TAPANULI DISTRICT
}

\author{
Ismail Fauzi Siregar, A H Daulay, T H Wahyuni, M Tafsin, S Umar \\ Animal Production Study Program Faculty of Agriculture, \\ Universitas Sumatera Utara. \\ Medan 20155, Indonesia \\ E-mail : ismailfauzi27@gmail.com
}

\begin{abstract}
Demands of animal foods from livestock (meat, eggs and milk) over time tends to increase in line with population growth, income, nutrition awareness, and improvement in education levels. But even though it has increased, the level of meat consumption of the Indonesian people is still categorized as very low. This study aims to determine the social and economic characteristics of households and analyze the factors that influence consumption of household beef in Pandan District. The analytical method used is descriptive analysis, namely by observing directly the social and economic conditions of the household, then using a questionnaire to obtain data on the socio-economic conditions of the household. The method of multiple linear regression analysis is used to analyze the factors that influence the consumption pattern of the household beef. The results of the study show that consumers of beef in Pandan Subdistrict have different socio-economic characteristics, both in terms of education, age, number of family members and income. The socio-economic characteristics of beef consumers, namely education, age, number of family members and income significantly influence the amount of consumption simultaneously. Age, number of family members and income have a partial effect on the amount of beef consumption, while the education variable does not have a partial effect on the amount of beef consumption.
\end{abstract}

\section{Introduction}

The development of livestock in Indonesia, especially ruminants, is expected to be one of the locomotives of development, especially in providing sources of animal protein in the form of meat and milk in order to increase people's food consumption. Human demands for livestock include meat, milk, fur, hair, and energy from these animals. Especially meat, meat demands in Indonesia are filled with beef, goat, lamb, duck, and chicken. The highest demand for meat in Indonesia on average comes from broiler chicken meat or known as broiler chicken. Demand for animal foods from livestock (meat, eggs and milk) over time tends to increase in line with population growth, income, nutrition awareness, and improvement in education levels. Meanwhile the supply of sources of animal protein, especially meat, still cannot compensate for the increasing number of domestic demand. But what is also important is that as we strive to develop the livestock sector to be even better, we must also pay attention to the socio-economic status of the people who will later become consumers. It can be said that the development of the livestock sector will be a waste if the level of income of the people themselves is still very low today. Although increasing, but the level of meat consumption of the people of Indonesia is still categorized as very low. The following is a table of meat production in Central Tapanuli district. 


\section{Materials and Methods}

This research was conducted in June-July 2018 in Pandan Sub-district, Central Tapanuli District.

\subsection{Method of Determining Research Locations}

The method of determining the research area was done purposively (intentionally), namely in the District of Pandan. Pandan Subdistrict was chosen because this area has the largest number of households compared to the other Sub-districts, including Tukka and Sarudik Districts.

\subsection{Method of Determining Sample Amount}

Based on data from the Central Bureau of Statistics Central Tapanuli District (2017), the number of households in Pandan Sub-district is 11072 households. The number of samples taken in this study is calculated in advance to be able to represent the large population in the study area.

\subsection{Method of collecting data}

Data collected in this study consisted of primary data and secondary data. Primary data obtained from interviews using questionnaires with households (respondents) that have been prepared in advance. Secondary data was obtained from relevant agencies and agencies such as the Agriculture and Animal Husbandry Service Office, Central Statistics Agency (BPS) of Central Tapanuli Regency and North Sumatra Province as well as other literature such as journals and research results that support this research.

\subsection{Data Analysis Methods}

Problem identification 1, was analyzed descriptively by observing and analyzing the pattern of beef consumption of household in Pandan sub-District, Central Tapanuli Regency. Problem identification 2 was analyzed using Multiple Regression Analysis through the SPSS program (Statistical Product and Service Solution).

\subsection{Model Conformity Test (Test of Goodness of Fit)}

\subsubsection{Coefficient of Determination (R2)}

The coefficient of determination R2 is a statistical value calculated from sample data. This coefficient shows the percentage variation of all dependent variables that can be explained by changes in explanatory variables.

\subsubsection{Simultaneous Test (F Test - Statistics)}

The $\mathrm{F}$ test is used to show whether all the independent variables entered into the model simultaneously have a significant effect on the dependent variable.

\subsubsection{Partial Test (Statistic t Test)}

The t test is used to show whether all the independent variables entered into the model partially have a significant effect on the dependent variable.

2.5.4. Test of Classical Assumptions

Classic assumption test is a statistical requirement that must be fulfilled in the multiple regression analysis based on Ordinary Least Square (OLS). In principle, the built-in linear regression model should not deviate from the BLUE assumption (Best, Linear, Unbiased, and Estimator). There are three classic assumption tests that will be used in this study including normality, heterocedasticity, and multicolinearity tests. 


\section{Results and Discussion}

\subsection{Classic assumption test}

This test is carried out to test whether the data is suitable for use or not. Tests are carried out using the Normality, Multicollinearity, and Heterocedasticity test. The following is an explanation of each of these tests.

3.1.1. Normality test

Table 1. Normality test

\begin{tabular}{lll}
\hline & & Unstandardized \\
& & Residual \\
\hline $\mathrm{N}$ & & 99.000 \\
Normal Parametersa & Mean & 0.000 \\
& Std. Deviation & 0.732 \\
Most Extreme Differences & Absolute & 0.087 \\
& Positive & 0.087 \\
& Negative & -0.049 \\
Kolmogorov-Smirnov Z & & 0.868 \\
Asymp. Sig. (2-tailed) & & 0.438 \\
\hline
\end{tabular}

the results of the data spread around the diagonal line and follow the direction of the diagonal line and the $\mathrm{P}$-value $=0.438$ which is greater than 0.05 , so it can be concluded that the residuals are normally distributed.

3.1.2. Test Symptoms of Heteroscedasticity

The Heteroscedasticity test is conducted to test whether in the regression model there is an inequality of residual variations, one observation to another observation.

Table 2. Test Symptoms of Heteroscedasticity

\begin{tabular}{lll}
\hline Model & T-value & P-value \\
\hline (Constant) & -0.007 & 0.994 \\
Education & 1.152 & 0.252 \\
Age & 0.883 & 0.380 \\
Number of Family & -0.265 & 0.791 \\
Income & 1.732 & 0.087 \\
\hline
\end{tabular}

3.1.3. Multicollinearity Symptom Test

Table 3. Multicollinearity Symptom Test

\begin{tabular}{llllll}
\hline & $\begin{array}{l}\text { Amount } \\
\text { of Meat } \\
\text { Consumpt } \\
\text { ion }\end{array}$ & Education & Age & $\begin{array}{l}\text { Number } \\
\text { Family }\end{array}$ & of Income \\
\hline $\begin{array}{l}\text { Amount of } \\
\text { Meat }\end{array}$ & 1.000 & 0.110 & 0.063 & -0.021 & 0.126 \\
$\begin{array}{l}\text { Consumption } \\
\text { Education }\end{array}$ & 0.110 & 1.000 & -0.357 & 0.518 & 0.286 \\
$\begin{array}{l}\text { Age } \\
\text { Number }\end{array}$ & 0.063 & -0.357 & 1.000 & -0.510 & 0.045 \\
$\begin{array}{l}\text { Family } \\
\text { Income }\end{array}$ & -0.021 & 0.518 & -0.510 & 1.000 & 0.052 \\
\hline Based & 0.126 & 0.286 & 0.045 & 0.052 & 1.000 \\
\hline
\end{tabular}

Based on the classic assumption test, the data used have normal residual values, no heterocedasticity, and no multicollinearity. So that the data is feasible for further analysis. 


\subsection{Regression Equations}

Regression estimation equation is a systematic formula that shows the relationship between one variable or several independent variables to the dependent variable.

$\mathrm{Y}=\mathbf{0 , 1 2 2}+(\mathbf{0 , 0 5 8}) \mathrm{X} 1+(-\mathbf{0 , 0 0 1}) \mathrm{X} 2+(-\mathbf{0 , 0 1 8}) \mathrm{X3}+(\mathbf{0 , 0 0 0 0 0 0 0 4 6 1 9 )} \mathrm{X} 4$

obtained a constant value of 0.122 . This shows that the effects of the independent variables of education, age, number of family members and income influence the dependent variable amount of household beef consumption is 0.122 or if the value of the independent variable is considered to be zero $(=0)$, then the value of the dependent variable is meat consumption beef is $0.122 \mathrm{~kg} /$ month.

\subsection{Model Conformity Test}

\subsubsection{Determination Coefficient Test $\left(\mathrm{R}^{2}\right)$}

The coefficient of determination test is to find out how far the independent variable affects the dependent variable. Based on the analysis, the coefficient of determination was 0.721 which means that the independent variables that were used were able to influence the dependent variable by $72.1 \%$ while $27.9 \%$ was influenced by other factors.

Table 4. Determination Coefficient Test $\left(\mathrm{R}^{2}\right)$

\begin{tabular}{lllll}
\hline Model & $\mathrm{R}$ & R Square & Adjusted R Square & Std. Error of the Estimate \\
\hline 1 & 0.849 & 0.721 & 0.709 & 0.074 \\
\hline
\end{tabular}

3.3.2. Simultaneous Test (F Statistics)

Table 5. Simultaneous Test (F Statistics)

\begin{tabular}{lllllll}
\hline Model & & Sum of Squares & Df & Mean Square & F & Sig. \\
\hline 1 & Regression & 201.370 & 4 & 50.342 & 66.045 & $.000^{\mathrm{a}}$ \\
& Residual & 71.651 & 94 & .762 & & \\
& Total & 273.020 & 98 & & & \\
\hline
\end{tabular}

From the results of the analysis in Table 9, the probability is smaller than 0.05 , which means that education, age, number of family members, income simultaneously affect the amount of consumption of community beef. Therefore, a further test was conducted, namely the statistical $t$ test to see the variables that affect the amount of consumption of beef in the community.

\subsubsection{Partial Test (Statistical T Test)}

Tabel 5. Partial Test

\begin{tabular}{lll}
\hline Model & t-count & Sig \\
\hline (Constant) & 2.359 & 0.020 \\
Education & 2.718 & 0.008 \\
Age & -.835 & 0.406 \\
Number of Family & -3.041 & 0.003 \\
Income & 13.576 & 0.000 \\
\hline
\end{tabular}

Education will determine the type of work a consumer has. Consumers who have better education will be very responsive to information, education also affects consumers in the choice of products and brands. Different education will cause different tastes of consumers. Low education will also reflect the type of work and income and purchasing power of these consumers [1].

In choosing a food menu that has adequate energy and protein content and choosing the right type of food composition, a relatively high level of knowledge is needed, especially the level of knowledge (age) of housewives who play a very important role in determining household consumption decisions [2]. 
The more number of household members, the more food needs (meat) consumed will vary because each member of the household has different tastes. For households with many household members, the quantity factor takes precedence over quality factors, so that all family members are expected to be evenly divided [3].

Revenue is something that affects consumers in terms of economic factors. Where on economic factors there are price factors \& consumer income factors. The income factor is one of the biggest things affecting consumers in making purchasing decisions. With the amount of consumer income so that consumers are able to objectively decide on all primary, secondary, and tertiary needs [4].

\subsection{Factors Affecting Consumption of Beef}

\subsubsection{Education}

The results of the education analysis of the amount of beef consumption have a regression coefficient of 0.058 , which means that if the education level increases by one unit, it will increase the amount of beef consumption by $0.058 \mathrm{~kg} /$ month. with the results of the education level variable having a significant influence on the trust level of 90 percent. With a sufficient level of education with the high school class and above, of course, they will have broader general knowledge than the level of education below [5]. That way, someone can be more aware of how important something is without regard to their capacity just to get something. With a sufficient level of education, one will realize the importance of consuming beef and trying to get it.

\subsubsection{Age Variable (X2)}

The results of age analysis on the amount of beef consumption have a regression coefficient of $-0,001$, so every 1 year increase in age causes a decrease in beef consumption of $-0,001 \mathrm{~kg} /$ month assuming other variables are considered constant. The negative sign at age shows a negative influence on the amount of consumption of beef, which means that if age increases, the amount of consumption will decrease.

dengan hasil variabel usia memiliki pengaruh signifikan pada tingkat kepercayaan 95 persen. Dapat dilihat pada Tabel 8 , bahwa responden yang paling banyak adalah kelompok usia yang tergolong muda yaitu 20-39 tahun dengan persentase 52.53\% [5]. This shows that respondents have a productive age. The more people who are productive, the level of consumption will increase. This is because the person gets the opportunity to work so he will get additional income. Increased income will increase purchasing power. Vice versa, in the age group that is classified as old, 40-59 years old has begun to enter a less productive age.

\subsubsection{Variable Number of Family Members (X3)}

The results of the analysis of the number of family members on the amount of beef consumption have a regression coefficient of -0.018 , so each increase in the number of family members of 1 soul causes a decrease in beef consumption of $-0.018 \mathrm{~kg} /$ month assuming other variables are considered constant. The negative sign on the number of family members shows a negative influence on the amount of consumption of beef, which means that if the number of family members increases, the amount of consumption of beef will decrease. This result is in line with the research conducted by [6] which has a regression coefficient value of -0.820 which means that every increase in the number of family members of 1 soul has a negative influence on the bound variable at a 95 percent confidence level. It should also be noted that the commodity studied is beef which has a higher price than other types of meat. It should also be noted that from the data of 99 samples, it was found that the average family income was only around 6 million rupiah, where the sample would tend to think that beef was expensive so decided to consume other types of meat and with a large number of family members more important than quantity. 


\subsubsection{Income Variable (X4)}

he results of the income analysis on the amount of beef consumption have a regression coefficient of 0.00000004619 , so any increase in income of IDR 1,000,000 - causes an increase in beef consumption of $0.04619 \mathrm{~kg} / \mathrm{month}$ assuming other variables are considered constant. A positive sign on income shows a positive influence on the amount of consumption of beef, which means that if income increases then the amount of consumption will also increase. This result is in line with research conducted by [6] with the results of income variables having a significant effect on the level of trust 95 percent and the regression coefficient value is 0.790 which means that it has a positive effect on the dependent variable. The higher a person's income, the purchasing power of an item will increase. This makes respondents' purchasing power for beef increase when income increases. The income variable has a significant but not so large effect on beef consumption because indeed meat consumption per capita is very low at $2.9 \mathrm{~kg}$ every year.

\section{Conclusions}

Consumers' socio-economic characteristics, namely education, age, number of family members and income have significant effect simultaneously or overall on the amount of consumption of beef. Educational factors, number of family members and income have a significant or partial effect on these factors on the amount of beef consumption, while the age variable does not have a partial or special effect on these factors on the amount of beef consumption.

\section{References}

[1] Sumarwan. 2004. Pola Konsumsi Pangan, Dalam Pengantar Pangan dan Gizi. Jakarta: Penebar Swadaya

[2] Djauhari A dan S Friyanto. 1993. Ciri-ciri rumah tangga defisit energi di pedesaan Jawa Tengah. Forum Agro Ekonomi, 2 (2), 60-67.

[3] Suyastiri NM. 2008. Diversifikasi Konsumsi Pangan Pokok Berbasis Potensi Lokal dalam Mewujudkan Ketahanan Pangan Rumah Tangga Pedesaan Di Kecamatan Semin Kabupaten Gunungkidul. Jurnal Ekonomi Pembangunan Vol. 13 No 1, April 2008. Hal 51-60

[4] Pramono A. 2001. Perilaku Konsumen Rumah Tangga dalam Memilih Daging Sapi di Perumahan Indra Prasta Bogor [skripsi]. Bogor: Fakultas Pertanian, Institut Pertanian Bogor.

[5] Dillago Z. 2011. Analisis permintaan daging ayam pada tingkat rumah tangga di Kecamatan Tobelo Kabupaten Halmahera Utara. Jurnal Agroforestri. 7 (3) : :16-24

[6] Fausayana I, Marzuki MA. 2017. Analisis faktor-faktor yang mempengaruhi permintaan telur ayam ras di kota kendari dan hubungannya dengan keberdayaan peternak. Jurnal Sosio Agribisnis. 1 (1) : 32-46 